\title{
Communicating Elevated Academic Expectations: Positioning Students as Thinkers with Ideas to Share
}

\author{
Jennifer Mitton, St. Francis Xavier University
}

Lia Lewis, North Nova Education Centre

Savannah MacDonald, Northumberland Regional High School

\section{Authors' Note}

Correspondence concerning this article should be addressed to Jennifer Mitton, Faculty of Education. Email: jmitton@stfx.ca

\begin{abstract}
The focus of this qualitative study is upon 15 Grade 12 students situated in an English Communications (ECM) classroom in rural Nova Scotia and the impact a daily classroom circle had upon their academic engagement. ECM is intended for students who may require further support to develop their skills as readers, writers, and language users as they enter the job market or community colleges. There is no formal curriculum for ECM, and often the demographics of such classrooms are comprised of some of the province's most vulnerable populations. In this paper, we demonstrate the impact the daily classroom circle had upon late adolescents' understanding of themselves as thinkers with ideas to share. Overall, we see this study as significant for teachers in high-poverty contexts, particularly the importance of using a classroom circle as a consistent space to communicate elevated expectations for students who have experienced academic struggles.
\end{abstract}

Keywords: adolescent literacy; circle routines; qualitative case study; restorative practices 


\section{Communicating Elevated Academic Expectations: Positioning Students as Thinkers with Ideas to Share}

Lia $^{1}$ greeted me as she wrote the agenda on the whiteboard asked if I might pass out the novel Night $^{2}$ (Wiesel, 2006) to each student. Turning to the class, Lia explained that the question to be discussed as a quick write in their journals and later, more fully, in the classroom circle was the same question. Lia explained at the end of Chapter 2, the author, Elie Wiesel, had a defining moment and asked the students what it was. Two students suggested "hatred" and "nothing"; Lia said both were correct although hatred was, for Wiesel, the defining moment in this instance, as it was the first time he could remember feeling such emotions. Lia said, "The question I am asking you to consider is: What is a defining moment in your life?" (Field notes, October 25, 2017)

This moment was a typical beginning in Lia's Grade 12 English Communications (ECM) class located in a mid-sized high school in rural Nova Scotia (NS). ECM is intended for students who may require further support to develop their skills as readers, writers, and language users as they enter the job market or community colleges. There is no formal curriculum for ECM, and often the demographics of such classrooms are comprised of some of the province's most vulnerable populations. ${ }^{3}$ For the purposes of teaching ECM, teachers are expected to adapt grade-appropriate, academic English curriculum and outcomes. While the opening moment highlights a common routine that most literacy teachers and teacher educators will recognize, what made it remarkable was how the classroom circle served as an instructional signpost for literacy activities and how students, with histories of academic struggles, positively responded to the daily routine.

As an experienced teacher and department head of English, Lia chose, and regularly scheduled herself, to teach this course. In NS it is not uncommon for early career teachers and/or teachers with little to no training in English literature content or English Language Arts (ELA) pedagogy to teach ECM. Consistently, Lia directly, and indirectly, demonstrated to students that they could use ideas from their own lives to inform their thinking, reading, writing, and analysis of texts. Informed by Lia's understanding of restorative practices (Watchel, 2016) as well as the learning principles underlying literature and Socratic circles (Moeller \& Moeller, 2013), we present Lia's daily classroom circle as an example of pedagogical bricolage ${ }^{4}$ (Campbell, 2019).

Overall, we see this study as significant for NS teachers, particularly the importance of elevating academic expectations for students in ECM classrooms; we also believe it may resonate with others who find themselves teaching in contexts with similar constraints. Because few studies have considered the views of late adolescents ${ }^{5}$ situated in high-poverty rural school contexts, and their understanding of how they might apply literacy skills in contexts beyond the classroom (Behizadeh, 2014a), the purpose of this paper is to tease out, and demonstrate, the impact a classroom circle routine had upon 15 Grade 12 students' understanding of themselves as thinkers with ideas to share.

\section{Teasing Out the Potential of Circle Routines With Learners who Struggle Academically}

Scholars agree that when understanding and assessing learners who experience challenges with literacy (Bauer \& García, 2002; Dawson, 2009; Ganske et al., 2003; Phegley \& Oxford, 2010, Pitcher et al., 2010) there are multiple factors to consider (some of which include home context, cultural background, prior learning experiences, teacher expectations, and the interplay of these elements). While it helps if adolescents feel a sense of investment in the development of their 
literacy abilities (Dawson, 2009), teachers need to be clear in their overall understanding of $21^{\text {st }}$ century literacy demands and pedagogical approaches that support and engage learners, particularly when assessing those who struggle (Bauer \& García, 2002; Dawson, 2009; Ganske et al. 2003; Minguela et al., 2015; Peskin et al., 2010; Van Zoost, 2011).

The ideas underlying pedagogical practices used to inform the facilitation of circle routines are complex. Although circle-based activities and routines in secondary ELA classrooms are widely understood in terms of design and implementation, how they pedagogically unfold varies in response to teacher beliefs and educational backgrounds, curricular purposes, and underlying approaches intersecting with age range and abilities of learners. For example, in the NS Regional Centre for Education ${ }^{6}$ where the study took place, relational principles informing teacher and student relationships are based upon a province-wide project focused on a restorative approach in schools (NS Government, n.d.). With the backdrop of this endeavor in mind, in our review of the literature, we were mindful to consider the recent influences of a restorative approach upon ELA educators, as they engaged in pedagogical practices informing the facilitation of circle routines, while we also explored research about the benefits of common circle activities (i.e. literature circles and Socratic circles) that promote active literacy engagement in the teaching and learning of ELA (Moeller \& Moeller, 2013).

\section{The Benefits of a Restorative Approach and its Practices}

The interest in community-building approaches informing relationships and interactions in schools has seen the emergence of a restorative approach (Schumacher, 2014), as many schools, districts, and systems have sought alternatives to zero tolerance policies (APA Zero Tolerance Task Force, 2006). Evolving out of restorative justice work in the judicial system (Llewellyn et al., 2013) and based upon ethics of justice and care (Noddings, 2013), a restorative approach aims at fostering open communication through a collection of restorative practices in which affective statements and questions may inform conversations, meetings, conferences, and classroom circles (CCRCE, n.d.; Llewellyn et al., 2013; NS Government, n.d.). As restorative practices are focused on communication and daily interactions that capitalize on "the use of informal and formal processes that precede wrongdoing, those that proactively build relationships and a sense of community to prevent conflict and wrongdoing" (Watchel, 2016, p. 1), gathering in circles as a way to foster communication is viewed as an essential component (Gregory et al., 2016; Ortega et al., 2016; Schumacher, 2014). Convening in circles for the purposes of building relationships and discussing issues relevant to communities is an ancient practice and way of knowing among Indigenous communities and peoples (Graveline, 1998; Peltier, 2017; Pete, 2004); the practice of meeting in circles using an approach informed by a consensus- and relationship-building process is recent phenomenon in school contexts. Most common to restorative practice circles are approaches that address conflict or disruptive social behaviors (peacemaking circles) and those that nurture relationships as part of inhibiting future conflict or rule breaking (proactive circles) (Costello et al., 2010).

The bulk of school-based research on restorative practices has focused on their impact, particularly in the decrease of disruptive student behaviors and declines in suspensions and expulsions (Gregory et al., 2016) as well as their positive influence upon school culture, social skill development, peer to peer interactions, and teacher-student relationships (Schumacher, 2014; Ortega et al., 2016). Altering the emphasis from blame and reprimand to a focus on developing and supporting affirmative relationships, scholars have attributed positive behavioral results to the implementation of a restorative approach and its practices in schools (Gregory et 
al., 2016; IIRP, 2009; Ortega et al., 2016). Little research has considered the impact of restorative practice principles upon teacher instructional decision-making, particularly through the responses and perceptions of adolescents who struggle academically.

\section{Circle-Based Routines and Activities in Secondary ELA Classrooms: Benefits and Limitations}

The secondary ELA classroom is an increasingly complex context where expectations for teachers and learners are multifaceted. Connected to not only traditional emphases on reading and writing, expectations are also informed by approaches and ways of thinking related to enhanced usage of alternative texts, contemporary media, and instructional technology (Schoffner et al., 2010) for the purposes of deepening communication, comprehension, construction of knowledge, and critical thought (Gee, 2001, 2007; Kalantzis \& Cope, 2011; Kane, 2011; Lind, 2008; Pahl \& Rowsell, 2012; UNESCO, 2008). Circle routines and activities are well aligned with the aims of 21 st century literacy teaching and learning, as they function, when effective, in ways that enable learners to capitalize on opportunities for deepening critical thinking, acquiring and applying academic vocabulary, and developing analytical skills using a variety of texts and contemporary situations.

\section{Benefits and Limitations of Literature Circles}

A common circle-based routine in ELA is literature circles (Daniels, 2006; Eeds \& Wells, 1989; Thein et al., 2011; Young \& Mohr, 2018); a strategy in which small groups of learners engage in focused discussions upon student-selected texts. Literature circles are generally depicted as providing consistent routines for learners to engage in conversation about chosen texts in which they have a genuine interest (Daniels, 2002; Daniels \& Steineke, 2003; Moeller \& Moeller, 2013). Although a bulk of the research on literature circles has tended to focus on application and design (Almasi et al., 2001; Bond, 2001; Clark, 2009; Daniels, 2002; Day \& Kroon, 2010), scholars have found that literature circles do foster student engagement and satisfaction (Batchelor, 2012; Flowerday et al., 2004; Moskal, 2019; Peralta-Nash \& Dutch, 2000). Their durability and long serving success in ELA classrooms may be attributed to what Daniels (2006) summarized as four key principles: engagement, choice, responsibility, and research. Much has been written about the positive benefits of literature circles upon learning (Young \& Mohr, 2018) in how they increase problem solving skills (Blum et al., 2002), improve reading comprehension (McElvain, 2010), boost language learning ( $\mathrm{Su} \& \mathrm{Wu}, 2016$ ), bolster decoding and vocabulary development (Piazza \& Duncan, 2012), and strengthen reading strategy use across a range of reading abilities (Whittaker, 2012). Some scholars also attribute regular student participation in literature circles to enhancing inclusive learning environments (Blum et al., 2002; Whittaker, 2012). Although there is wealth of research championing literature circles, scholars have identified limitations, particularly the tendency to be overly prescriptive (Daniels, 2006), the ways student interactions may be based on perceptions of ability (Allen et al., 2003), the potential for student discussions to reinforce stereotypes (Alvermann, 1995), and in how students may fail to take up critical perspectives when discussing texts (Thein et al., 2011). These critiques highlight the significance of teacher pedagogy upon the structure and facilitation of literature circles (Sanacore, 2013).

\section{Benefits and Limitations of Socratic Circles}

To foster exploratory talk and support deepening understanding of a topic among learners, Socratic circles are constructed around the discussion of purposeful open-ended questions 
(Copeland, 2005). Ideally, Socratic circles are designed to create a dialectic as a way to provoke among participants deeper understanding of complex ideas. The success of this approach depends upon a well-developed opening question in connection to a text that students have critically read, one that has no right answers, with the potential to foster speculation, evaluation, clarity-seeking, and the generation of new questions (Styslinger \& Overstreet, 2014; Styslinger $\&$ Pollock, 2010). Typically, students sit in two concentric circles with the inner circle discussing the question and text and the outer circle actively listening, taking notes, and providing response to the inner circle about the process of discussion (Brown, 2016; Copeland, 2005). Advocates of Socratic circles argue that the strategy provides opportunities for students to take partial control, identify the direction of discussion, and govern collectively where students and teachers' opinions are weighted equally (Copeland, 2005; Styslinger \& Pollock, 2010). Scholars have attributed the regular use of Socratic circles to enhancing abilities to ask better questions (Thomas \& Goering, 2018), to use evidence to support arguments (Brown, 2016), to develop critical awareness about social, cultural, political, and historical events (Balbay, 2019), and to participate more fully during a variety of discussions (Dean et al., 2016). Despite the advocacy for the implementation of Socratic circles, little research has focused on teacher pedagogy and the facilitation of this teaching strategy (Brown, 2016; Dunne, 2014; Friesen \& Stephens, 2016; Higham et al., 2014; Styslinger \& Overstreet, 2014). The little that is known about the knowledge and skill needed to successfully implement and facilitate Socratic circles brings into focus the need to better understand how teachers may use this strategy to engage learners who identify as experiencing struggles with literacy.

\section{Looking Across Literature and Socratic Circles}

Of particular interest to our focus was the significance of teacher pedagogy during the enactment of circle routines and activities. A review of the literature revealed an abundance of studies that focused directly on the design, implementation, and procedures associated with the practical facilitation of common circle routines and activities in the teaching of ELA. The remainder identified the impact regular circle routines have upon student learning. Overall, there is limited research on how secondary students who academically struggle perceive participation in classroom circles, on how they come to understand themselves as learners in response to engaging in such processes, and, little to no research, on the influence of restorative practices on adolescents' willingness to persist with circle routines and activities that engage literacy knowledge and skills. In what follows, we explore the experiences, and perceptions, of 15 late adolescents participating in a classroom circle that was a regular feature of their ECM class.

\section{Theoretical Framework}

Attempting to understand what adolescents' perceived as useful and authentic to their literacy learning (Behizadeh, 2014a), particularly when they had experienced struggles, required the design of the study to be exploratory and informed by a willingness to inquire into the observed and told stories (Butler-Kisber, 2010) that adolescents shared over time. We draw upon an understanding of 21 st century literacy and its multifaceted emphasis on the kinds of literacy practices and skills individuals need to successfully communicate and navigate technologically advanced societies. Viewing literacy in this way not only allows for reading and writing, but also acknowledges a multitude of social practices, purposes, and interactions used to deepen understanding, communication, critical deliberation, and fostering of knowledge in contextually relevant ways (Gee, 2001, 2007; Kalantzis \& Cope, 2011; Pahl \& Rowsell, 2012; UNESCO, 2008). As part of this view, particular emphasis is upon how teachers and learners interact in 
classroom contexts shaped by local constraints and social requirements (Beach et al., 2016; Downer et al., 2010; Forzani \& Leu, 2017). Buckelew and Ewing (2019) described the ELA classroom as a unique environment where

individual components of the classroom ecosystem are not static, but fluid and dynamic; the information and lessons shared are reciprocal. Both the teacher and students are transformed by each other. While the teacher may be the lead facilitator, the interdependent and transactional nature of the ecosystem acknowledges that both teacher and student are transformed by the transactions that occur in the classroom. (p. 14)

The complexity of such a learning environment grounds our understanding of the possibilities and challenges associated with teaching and learning in ELA classrooms, where "a conundrum of change" (Forzani \& Leu, 2017, p. 20) is expected and can be embraced. Leu et al. (2013) argued that the nature of literacy in the $21^{\text {st }}$ century is deictic in how the meaning of the word changes rapidly in response to emerging information and communication technologies, all of which have new literacies demands (Leu, 2000; Pahl \& Rowsell, 2012).

Circle routines and activities are well aligned with the aims of 21 st century literacy teaching and learning, as they function, when effective, in ways that enable learners to capitalize on opportunities for deepening critical thinking, acquiring and applying academic vocabulary, and developing analytical skills using a variety of texts and contemporary situations in community with others. The relationship building and consensus-seeking nature of restorative practices further complements the academic emphasis found in many circle routines and activities, as the aims of nurturing relationships and communication, we observed, enabled the participants of our study to take that leap of faith, share ideas, and respond to others. In the daily classroom circle, participants were positioned as holders and constructors of knowledge and this way of knowing is reminiscent of what Aoki (1993/2004) referred to as "teaching as in-dwelling between two curriculum worlds," where the origins of curriculum, "curriculum-as-plan" informed Lia's knowledge of the achievement of outcomes and "curriculum-as-lived" revealed her understanding of the uniqueness of those participating (pp. 14-15). In this way, the daily classroom circle served to position, honor, and remind students of who they were and what they knew. In short, this regular routine was about students and their lives, first, and curriculum as mandated outcomes, second (Connelly \& Clandinin, 1988; Schwab, 1983).

Of particular importance to our inquiry were our attempts to better understand and document how learners, who have experienced academic challenges, were engaged in the ECM classroom. In our design of the study and recursive analysis of data, we were drawn to scholars that advocated for the potential of integrating restorative practice principles into daily instructional practices (Gregory et al., 2016), noting where we saw particular emphasis on literacy teaching and learning applicability. For example, Winn (2013) argued for the reimagining of the English classroom as "restorative English education," an approach that includes restorative justice principles, practices, and circle processes as secondary youth and teachers use literature and writing "as sites of restoration and peacemaking" (p. 129). To counter the punitive nature of zero-tolerance policies and their tendency to categorize, mark, and segregate particular youth, Winn (2013) argued that ELA teachers need to incorporate "a discourse of restoration" and "reimagine English classrooms as sites for relationship-building, peacemaking, and peacekeeping" (p. 127). For us, the impact of restorative English education is most visible during the daily practice of classroom circles, as it is a process bounded by time, place, and social interactions as participants (teacher and learners) engage in dialogue about 
literature and contemporary issues in ways that are personally relevant, and which position everyone as thinkers who are working at finding and expressing voice as they mediate and engage with others (Winn, 2013).

\section{Foundational Considerations: Context}

The study's location, demographics, and adolescent literacy and teacher pedagogy considerations are significant threads that we chose to include throughout this paper. We view this combination of threads as an interconnected web; as one thread is pulled forward and discussed, it ripples across and brings forward the consideration of other threads. First, the student participants of this study attend an ECM class in a large high school situated in a high-poverty, rural location of NS. Their lives outside of school shaped and informed perceptions of their learning experiences in the ECM classroom as well as how they looked forward to life beyond graduation. Related to participant understanding of who they could be in ECM, and, arguably, into the future, was the pedagogical decision making of their teacher, Lia Lewis. As outlined in review of the literature, there are subtle differences among the purposes of circle routines, specifically, literature circles, restorative practice circles, and Socratic circles. For our purposes, we use the term "classroom circle" to convey the multifaceted nature of this routine in Lia's classroom.

Throughout the paper we maintain a focus upon the complexity of participants' lives in context, pulling forward these threads as relevant to the discussion. Below are the research questions of the study:

1. What are the perspectives of adolescents who have experienced academic struggles about the relevance of literacy to their lives beyond the classroom?

2. In what ways, if any, are secondary students academically engaged in the ECM classroom?

3. In what ways, if any, are secondary students' willingness to engage academically positively impacted by the classroom circle?

In the following methodology section, we discuss how these questions were addressed, as we inductively analyzed the data that emerged.

\section{Methodology}

Using a single qualitative case study design focused upon a common case (Yin, 2018), our aim was to document the everyday circumstances and conditions of student engagement in an ECM class. Yin (2018) suggested case study design is well-suited for research that seeks to understand a contemporary phenomenon and makes the assumption that such understanding will involve significant contextual considerations (Yin \& Davis, 2007). The premise underlying our intent in this study was to better understand the perspectives of high school students, specifically those who identified as experiencing academic struggles, about their experiences in ECM. We attended to how these individuals interpreted and attributed meaning to their experiences (Merriam \& Tisdell, 2016) about the kinds of literacy learning they saw as relevant/authentic to their lives outside of school, as they looked ahead to entering the job market or attending community college. Conducted over the course of the fall semester (October-January) in the academic year of 2017-2018, the study was situated in a Grade 12 ECM classroom located in a NS high school with a student body of roughly 900 students. Approximately 120 students are registered across Grade 11 and 12 ECM classes and typically there several sections of ECM in any given semester (e.g. Grade 11: 60 students; Grade 12: 60 students). 


\section{Establishing Classroom Circle Norms in ECM}

Although Lia approached teaching through a relational lens, she did not alway maintain intentional, restorative, and relational practices in her classroom setup, conflict resolution, and curriculum delivery. Lia's conscious effort and intentional practice to infuse restorative practices into her teaching developed as a result of struggling to connect with reluctant learners in ECM classes. Lia was first introduced to the language and specific strategies of a restorative and relational approach through formal and informal professional development opportunities. While these ideas felt familiar to her, she recognized the opportunity for further growth and development. For example, Lia learned that language is a significant component of restorative practices and is key in establishing and maintaining healthy and productive relationships. Drewery and Kecskemeti (2010) explained that words can be used to "open options, and invite the other into useful dialogue, rather than offering them positions that they may object to" ( $p$. 106).

Over time, Lia intentionally changed the physical setup of her classroom in order to facilitate a more student-centered environment and to encourage further development of authentic connections and relationships. Simple changes in the physical set up of Lia's classroom drastically shifted the interactions between the students, and between the students and her. Lia learned to start and end class in a circle formation, without physical barriers (such as desks) between people. While there is no magic in the circle itself, Lia observed, there was significance in ensuring that no one had their back to another person in the room. Because students had to look at one another and could no longer "hide" behind desks or cellphones, they were held more accountable to Lia, to each other, and to their own learning. In addition to changing the physical layout of her classroom, Lia also focused on more purposeful openings and endings to lessons. This strategy is restorative in nature because it fosters connection between students, student and teacher, and students and curriculum (Drewery \& Kecskemeti, 2010). She began to ensure that the opening and closing prompts (responses can be verbal, written, or both) provided opportunities for important information about the students as learners and as humans.

\section{Entering the Classroom and Data Collection Methods}

Once ethics approval was received from the Research Ethics Board at St. Francis Xavier University and permission was granted by the Regional Centre of Education, the first author, Jennifer visited Lia's classroom in early October 2017. The first visit was brief; its primary purpose was to provide Jennifer and the students an opportunity to meet and for the students to learn about the study. As a way of beginning, Jennifer, Lia, and the students sat in a circle and introductions were made. Following introductions, Jennifer first explained the concept of informed consent and emphasized that it was their decision whether, or not, they participated. They were also informed that they could withdraw from the study at any point and without penalty. During the opening conversation, some of the students expressed surprise over the fact that Jennifer, a university professor, wanted to spend time in their classroom. Later, Jennifer and Lia shared details about what to expect by participating, specifically, the duration of the study, the nature of Jennifer's observations, and the kinds of questions they could be asked during individual interviews. Also outlined was the amount of time that they could expect to invest in the study and Jennifer emphasized that their teacher, Lia, would not see transcripts of interviews until the semester was over and grades had been submitted. Students were encouraged to ask questions throughout as Jennifer and Lia described the study and its activities. To give students time to think over the invitation, Jennifer left the class after 40 minutes. Two weeks passed 
before Jennifer's return; during this period of time, Lia answered follow-up questions and collected consent from interested students. Out of 22 students, 15 agreed to participate.

As part of our focus on 15 Grade 12 ECM students, we were also deeply mindful of the school context in which the study was situated. Many of the students are bussed in from surrounding rural communities and in recent years the mid-sized town where the high school is located has experienced severe economic fallout due the closure of several significant industries. Frank and Saulnier (2017) identified the region as an area where child poverty rates are documented at over $30 \%$ and according to Statistics Canada data, NS is the lone province where child poverty has increased since 2015 (Statistics Canada, 2019). More recently, Frank and Fisher (2020) found that the number of children living in poverty in NS is close to one in four. It is important to emphasize the financial vulnerability of the context, as many of the youth who took part in this study experience poverty and/or home insecurity.

Between October 2017 and January 2018, Jennifer visited Lia's Grade 12 ECM class once a week and conducted a 75-minute observation for a total of 10 visits. During the observation, Jennifer wrote field notes on a laptop with a focus on participants' actions and words, as well as participants' responses to one another and classroom environment. As part of these visits, Jennifer also participated in the classroom circle. Depending upon the topic and student responses, classroom circles tended to run between 20 to 30 minutes; as described earlier, Lia employed circles to create relational connections among the group (with her and each other) and to foster academic connections to the texts and issues under examination. Field notes were shared with Lia at the end of every class; Lia added commentary to Jennifer's observations and contributed reflective field notes bi-weekly. To document student perspectives, Jennifer individually interviewed participants twice during the semester (the end of November and January). Finally, student samples of writing that focused on personal interests and out of school learning experiences were also gathered. The first item was a questionnaire that encouraged students to identify their interests in and outside of school (October) and the second item was a post mapping exercise where students self-identified positive attributes of their learning (January).

\section{Data Analysis Process and Activities}

We began our analysis by reading through the data sets and open coding (Merriam \& Tisdell, 2016), identifying repetitive instances of student behaviors and responses. This opening round of analysis was guided by our two primary research questions: What are the perspectives of adolescents who have experienced academic struggles about the relevance of literacy to their lives beyond the classroom? and, in what ways, if any, are secondary students academically engaged in the ECM classroom? These interrelated research questions drew our attention to the daily classroom circle. In next stage of analysis, we clustered tentative categories we each had developed, looking for common threads and differences. As we focused our gaze on these categories, we noted references to observable academic engagement connected to the classroom circle, moments where questions and discussion in preparation for the circle as well as during the circle later influenced student responses and interest in the same lesson. The development of this paper about the impact of the classroom circle on student willingness for learning was not something anticipated while planning or conducting the study. The presence of the classroom circle as influential emerged from the data, which caused us to create a third research question: In what ways, if any, are secondary students' willingness to engage academically positively impacted by the classroom circle? Once we identified the frequency of participants' mentions of 
the classroom circle, we reviewed the data with this lens and found examples across transcripts and field notes in which the classroom circle played a pivotal part in positively impacting student learning. Further analysis enabled us to identify patterns related to the relationship between the classroom circle and discernible student willingness in engaging in positive relational interactions as well as in literacy practices. Our understanding of student willingness and engagement is directly connected to documented frequency of participants' behaviors, particularly positive social interactions and persistence with literacy tasks (Francois, 2013), as they discussed and wrote about literature and current issues in ways that were personally authentic (Behizadeh, 2014a) and inclusive of others in the classroom as individuals with ideas and thoughts to share (Winn, 2013). In the next section, three themes are discussed using excerpts from interview transcripts and field notes of classroom observations. Each theme represents a recurring, common response to the circle over the course of the study and across data sets.

\section{Findings: The Positive Impact of a Classroom Circle on Late Adolescents Willingness to be Academically Engaged}

As the previous section describes, analysis of the interviews and observations led us to identify three main areas in which we saw positive impact of the classroom circle upon participants' willingness to be academically engaged. Part of this willingness, we believe, was attached to the nature of the practice in how students knew that the daily circle was bounded by a certain amount of time (20-30 minutes), a specific seating arrangement (circular configuration), and established parameters regarding social interactions (CCRCE relational principles). ${ }^{7}$ Enclosed in the trust and safety of the circle and knowing the social guidelines and expectations placed upon all involved, we observed the willingness of students to persist with topics under examination and to take risks with their thinking (Mitton \& Murray Orr, in review). The presentation of the three themes are organized to reflect the impact of the circle on students as well as its pedagogical complexity in how it is a two-fold process that requires concurrent self-reflection and awareness of others. The excerpts illustrate a holistic view of the theme under discussion and provide a sample of the frequency with which positive impact examples about the classroom circle were present in participants' accounts of their learning and in the field notes of classroom observations.

\section{Theme One: Circle Engagement as Opportunities for Developing Social and Communication Skills}

\section{Interview 1: November 30, 2017}

Student participants noted the importance of the classroom circle to how they interacted with one another. Participant recognition of the circle as significant for their learning happened gradually, however. We note in the first interview that a small minority of participants framed the daily classroom circle as something better suited for elementary; for example, one participant described the circle as being "like a kindergarten class a lot of the time, as opposed to a Grade 12 class" (Matt). While this was not a common response, it is important to highlight, as it may be partially attributed to participants' wariness of one another as well as to the negative stigma attached to ECM, a class widely known as the English course for students who were not going on to university studies. A few students were quick in the first interview to point out the differences among students and how this made for challenging learning conditions. For example, Matt explained that "this English class gets me quite stressed out ... just, the different types of people 
that are in our class ... I guess, I just have a hard time accepting it." Another student, Harper, said, that he had not "learned a lot in this English class; it's mostly [because] a lot of them are just goons." Contrary to these opinions, other students emphasized the variety of people in the class and saw the circle as a way to get to know them. For instance, Tom described the class as a context in which "everyone's got their own [story] ... they're pretty interesting ... Yeah. They all got their own stories to tell. Pretty interesting group overall, really."

\section{Interview 2, January 19, 2018}

By the end of the semester, the majority of participants demonstrated their awareness of how the classroom circle enabled them to successfully engage with peers who they did not know at the start of the semester. Participants, overall, attributed their participation in the daily circle as creating opportunities for social and communication skill development. A most notable shift was found in participants who in the first interview had expressed their disdain for the daily circle. For example, in the second interview, Matt, who had described the classroom circle as better suited for kindergarten-aged students, pointed out that "in ECM ... you're able to express yourself a lot more. It might not be an academic-based course but as far as real-life goes and the skills you need for actual everyday life, I find ECM is better for it." Harper, a student who had expressed negative opinions about some members of the class, identified how ECM was helpful for "our communications skills. They've gotten much better, all of us. At the beginning, our communication skills were horrible, but now they've gotten a lot better." In response to the question, what has been most beneficial for your learning in ECM, participants overwhelmingly, identified the classroom circle; for example, Beau pointed out that it was "definitely, the circle. To engage with everyone around." and Tom, echoing Beau, explained the biggest benefit in ECM was "the circle that we always had ... [it] helps you with your talking and sharing with other people." Viewing student participants' perspectives on the positive impact of the classroom circle upon their communication skills, enabled us to see the ripple effect the daily routine had upon students' willingness to engage in other literacy practices, particularly in the analysis of academic texts.

\section{Theme Two: Circle Engagement as Opportunities for Deepening Textual Connections and Fostering Stamina}

Throughout the study, we noted how the opening classroom circle provided opportunities for students to demonstrate their understanding of how to create connections across a wide range of texts. In the following we share three different excerpts from the same observation to highlight how the classroom circle engagement grounded and informed other stages of the lesson enabling students to not only show deeper learning but also a willingness to share ideas that were personally meaningful.

\section{Preparing for the Classroom Circle}

Lia greeted me as she wrote the agenda on the whiteboard asked if I might pass out the novel Night (Wiesel, 1960) to each student. Turning to the class, Lia explained that the question to be discussed in their journal and later in the classroom circle was the same question. Lia explained at the end of Chapter 2, the author, Elie Wiesel had a defining moment and asked the students what it was. Two students suggested "hatred" and "nothing"; Lia said both were correct although hatred was, for Wiesel, the defining moment in this instance, as it was the first time, he could remember feeling such emotions. Lia said, "The question I am asking you to consider is: What is a defining moment in your 
life?" Lia asked Nicole, a quiet girl seated close to her, if having Laura, her daughter, was a defining moment for her. Nicole smiled and said that becoming a mother was such a moment in her life. Lia provided a few other examples, "For example, when you got a job or when have to take care of someone else." Lia checked again to see if the examples helped student understanding. Lia asked Leo if he had an example about a defining moment and he suggested "getting a job"; Lia agreed. Lia moved about the room as students completed a quick write in their journals in response to the question (Field notes, October 25, 2017)

\section{During the Classroom Circle}

Using the responses from their journals, students took turns sharing examples of personal defining moments. Tom wrote about getting his driver's license and explained it was like getting freedom. Kasey was next and also identified getting his license as important and then shared a story about driving without a license a few times and getting caught by the police. Allan described the moment he realized he was good at technology and math and Leo explained how driving his dirt bike enabled him to go where he wanted to go ... half way through the circle the examples became gradually more personal ... Tucker quietly shared the moment when he won his age group at the Atlantic Canadian Bow Shooting Championship ... Lewis shyly described moving from PEI in Grade 9 and that it changed him for the better ... Harper told a story about hurting his ankle during a basketball game and how he had to get surgery; he said the pain was unlike anything he had experienced before and it now made him really careful when playing ... Matt quickly described the death of his grandmother two years ago and explained that the event had negatively impacted him and changed his decision making in "not always in a good way."

\section{Following the Classroom Circle: Analytical Discussion}

Lia praised their examples and suggested that they could put away their journals and return their seats. She asked them to turn to page 23 of Night and to make sure they had paper and something to write with ... Lia explained that while they read, they should pay attention to intense imagery because she expected them to find three vivid examples in the novel ... later, as they discussed a moment in the novel as a young boy comforted his mother who seemed to be going mad as she shouted about visions of fire as they approached the concentration camp inside the train, Lia asked why this was important. Allan suggested, "It shows that this place [Auschwitz] is making them purely mad." Kasey suggested that it shows the little boy's mother was vulnerable and that they both will probably be put to death. Leo suggested that the little boy was attempting to take care of his mother. Beau suggested this moment reminds him of the episode on the Walking Dead when the main characters arrive at Terminus and the group think it's a nice place until they figure out that it is evil. (Field notes, October 25, 2017)

Over the course of the study, examples of how the daily classroom circle positively impacted student engagement for the duration of the lesson were recurring. As depicted in this moment, the classroom circle served a two-fold purpose in how it provided structure to the topic under examination and in how it created opportunities for students to share ideas in varying ways: as they prepared for the circle (journal writing), as they engaged in the circle, listening and responding with personal examples, and later following the circle, as they analyzed the text (text annotation, writing, and discussion). While the lesson's central idea (the identification of a 
defining moment) enabled students to focus their thinking, we highlight how participation in the circle encouraged students to become more personal with their examples. Described in the order in which students took turns in the circle, the examples that were shared show how students gradually moved from safe answers (getting a driver's license) to examples of accomplishment (winning a major championship) to instances where pain was experienced physically (ankle injury) and emotionally (grandmother's death). More often than not we found student engagement in the circle positively rippled into the literacy activities that followed and it was common for students to persist with the topic previously explored in the circle. For instance, as evident in this lesson, we highlight students' ability to plausibly infer about the possible motives of the boy and his mother as well as one student's insight into the novel, Night, and the connection he made to the television series, The Walking Dead. In both instances, the moments focused upon characters' uncertainty as they entered unfamiliar contexts (Auschwitz and the post-apocalyptic community of Terminus) with the hopes that they may be safe places to only soon discover the danger of their new homes.

\section{Theme Three: Circle Engagement as Opportunities for Enhancing Understanding of Self and Others through Content}

For many students who take ECM, post-secondary plans tend to include entering the job market and/or attending community college; because of this one may wonder about the purpose and relevance of reading literature with students whose plans do not include university studies. To counter this perspective, we highlight sociocultural perspectives on literacy (Scribner \& Cole, 1981; Street, 1995) and the view that literacy is more than discrete sets of skill development located in academic settings. Classrooms, homes, peer groups, neighborhoods, schools, and so forth are part of who learners are and inform how they make sense of practices and events associated with literacy and texts (McCarthey \& Moje, 2002). Such perspectives emphasize that literacy is not just processes related to skills but are also connected to learners' identities, enabling learners to sharpen their gaze in the analysis of texts (Langer, 2002; Rosenblatt, 1995). Scholars also argue that the study of literature provides opportunities for learners to better understand themselves through the study of others (Darragh \& Boyd, 2019; Singer \& Smith, 2003). Of the literacy practices, events, and texts (Francois, 2013) in which participants were regularly engaged, the daily classroom circle provided students with the opportunity to collaboratively analyze academic content through the frames of their own lives.

Lia started the circle by asking the students about what has been going on lately in the school. Beau and Leo were quick to describe the fights on school property. Lia then went on to ask about what they and others did when they saw people fighting and Beau replied, "Nothing" ... Picking up on this idea, Lia explained that the day's focus is the idea of doing nothing, or indifference, which is connected to the book, Night, and what Elie Wiesel called "the danger of indifference." Lia explained that they would not read much today but would spend more time in circle and small groups discussing the idea of indifference. Lia said, "give me an example of seeing people indifferent to an event and of people not responding to what is happening." Beau described watching a couple fighting over a baby in a stroller and he called the police because he didn't think he could step in and do anything ... Harper described a disagreement between a couple outside of his house and when the girl broke down as the guy drove away, he stayed in his house and laughed. He explained this couple does this stuff all the time and he did not take it seriously ... later in the circle, Lewis asked for a repeat of the question; Lia reworded the question. Lewis 
replied that when he was younger, around the age of five, his parents were always fighting and that he wished he could have stepped in ... he said he wanted to help both of them, but he could not. The room got very quiet after he said this. ... At the end, Lia made a connection to Elie [Wiesel] and reminded them that Elie asked in the novel asked how women and children could be burned alive as the world remained silent. She said, "We're going to continue to explore this topic of indifference in small groups." (Field notes, November 10, 2017)

Lia was purposeful in the kinds of questions asked at the start of the classroom circle, and she made strategic use of school-based incidents to ground the conversation. As depicted in this moment, it was not uncommon for students to offer deeply personal experiences and ideas in response to Lia's question. Inside the circle, vulnerable responses like the one Lewis shared, were not unusual. Conversation in the circle tended to be circular in nature in how Lia focused the question at the outset by connecting it to the topic and/or text under examination and in how she returned to this focus at the end of the circle once everyone had shared. As emphasized in discussion of the second theme, the classroom circle was not separate from other literacy practices, events and texts in the classroom, rather, it informed all of these constructs and may be viewed as an example of "literacy as a social act" (Francois, 2013, p. 142).

As the circle unfolded each day, Lia did not censor ideas and modeled for students that it was appropriate and authentic to share real opinions. At times, some students attempted to outdo the preceding story through the sharing of vivid details that were sometimes violent and/or illegal. In such moments, Lia listened, asked follow-up questions, and responded in ways that showed her attempts to create space for their story, although she did not condone such behaviors and expressed her lack of approval if actions were illegal and/or vicious. The circle, for participants, was a space where they were positioned as thinkers: Academic texts were negotiated through personal connections and multiple interpretations were encouraged and viewed as essential to deeper understanding.

\section{Discussion: The Ripple Effect of the Daily Classroom Circle}

The purpose of this study was to better understand how students with histories of academic struggles understood the relevance of literacy to their lives and how they responded to learning in the ECM classroom. As students who had mixed feelings about school, we were curious about the kinds of practices, events, and texts (Francois, 2013) that would elicit their focus and engagement while supporting the development of their literacy skills. A formative presence in the backdrop of this study was the context in which it was located; a region where one in four children live in poverty (Frank \& Fisher, 2020), where the closing of industries has created severe financial constraints, and where job prospects in the area are limited. Much has been written about the impact of poverty on children and adolescents' academic achievement (Ahmar \& Anwar, 2013; Reardon, 2011; Sirin, 2005) and the compounding factor of attending schools located in low-income areas where higher rates of teacher turnover and resource constraints create additional barriers (Carver-Thomas \& Darling-Hammond, 2019). Scholars have argued that such conditions reduce opportunities for learners to achieve academic success, leading to feelings of frustration and discouragement in young learners (Joffe \& Black, 2012) with the potential to evolve into little academic motivation in adolescents (Breslau et al., 2009), and the increased likelihood of leaving school before completion of studies (Brownell et al., 2006; Brownell et al., 2010; Roos et al., 2006). 
With respect to the links between poverty and literacy, Statistics Canada (2020) reported that $13.8 \%$ of 15 -year-old youths across the nation had low literacy skills in 2018 and $11.7 \%$ of Canadian youth (15 to 24 years old) were not engaged in employment, education, or training in 2020. The lifelong implications of poverty further hampered by low literacy skills are revealed in unmet housing and health needs as well as chronic homelessness (Statistics Canada, 2020). Socio-economic disadvantage at the outset has lifelong implications not only in terms of reduced salaries but also in the actuality of shorter life spans (OECD, 2018, p. 3). Intergenerational mobility, the OECD (2018) argued, may be understood as "sticky floors" and "sticky ceilings," as children from disadvantaged backgrounds strain to move up the social ladder and as children from middle to high income families have opportunities hoarded to ensure their advantages.

Throughout the study we were mindful of the potential impact of our location upon the future prospects of student participants: The possibilities of their lives after graduation in terms of employment, post-secondary education, or training. Viewed through this lens, the role enhanced literacy skills can have upon individuals' lives comes sharply into focus, particularly the economic mobility that becomes possible with the advance of literacy skills and their positive ripple effect upon secure housing, food security, and health care access (OECD, 2018; Statistics Canada, 2020). To support social mobility, education is critical; curriculum and policy design can grant learners equal opportunities, access to high quality early and formal education while inhibiting early school leaving (OECD, 2018). Yet, in the NS context, formal curricular attention has not been given to ECM, circumstances which highlight not only the importance of experienced literacy teachers and their pedagogy (Campbell, 2019), but the pressures they experience.

Prior to implementing intentional restorative and relational approaches in her classroom, Lia struggled to engage the majority of her ECM students. Specifically, she struggled to engage them in deeper thinking in relation to texts introduced in class. Lia observed that students did not necessarily see themselves as capable of reading or connecting with novels, especially texts like Night. Many of her students were used to being given "lower level" reading material that they could read independently (or, as many students admitted, texts that they could easily "fake read"). In Lia's experience, many ECM students had learned to hide and remain hidden in English classrooms.

By implementing the classroom circle, Lia observed, students were unable to hide as easily and they became more accountable because they, literally, had to look one another in the eyes each day. This accountability was, at first, uncomfortable for many. As their confidence grew each class through meaningful check-ins, opening discussions, and supportive questioning of their ideas, however, Lia noted they began to rise to the occasion. Their responses to questions moved from safe and surface-level, to reflective and rooted in personal experience. Their desire to hide diminished more than students Lia had previously taught. They grew to believe that their voices mattered and were welcomed, and gradually Lia observed how they learned to take risks in their learning because they knew it was safe and meaningful to do so.

\section{Engaging Learners who Struggle Academically While Experiencing Poverty: The Challenges}

Given the lifelong implications of literacy, it is paramount to consider what kinds of pedagogical routines and activities positively engage learners who struggle academically while also experiencing poverty. Considerable attention has been given in the research literature to the 
value of differentiated literacy instruction and strength-based adaptations (Pitcher et al., 2010; Troyer, 2017) in response to adolescents' needs, interests, and preferred modes of communication and meaning making (Casey, 2008; Dressman et al., 2005; Franzak, 2006; Scheffel, 2012, 2016). Yet, challenges arise when convincing learners who have struggled in school to persist with cognitively demanding literacy tasks (Benko, 2016), particularly processes and products that are based on constructing knowledge and making claims using evidence and reasoning. Such tasks have particular literacy demands and scholars have found that learners who struggle with literacy, in particular, have a gap in their ability to decode words, decipher vocabulary, and understand sentence fluency (Lovett et al., 2012). While it is understood that developing such skills can be targeted in the teaching of reading and writing, (Kim et al., 2017; Murphy et al., 2017), what remains elusive is the kind of literacy practice, event, and/or text that will capture learner interest and willingness to persist, particularly when they have experienced academic struggles. Scholars have suggested that to have merit with learners, school-based literacy engagement needs to be perceived as authentic (Behizadeh, 2014a), as connected to real world examples, and as supportive (Josephs \& Jolivette, 2016; Scheffel, 2017; Thompson et al., 2008). If such conditions are in place, the research shows that adolescents are more likely to take an interest in literacy tasks (Ivey \& Johnston, 2015; Nystrand, 2006; Pittman \& Honchell, 2014). In knowing this, student-centred pedagogies (Behizadeh, 2014a, 2014b), out-of-school literacies (Corbett, 2005; Skerrett \& Bomer, 2011) and relevant young adult texts (Fogarty et al., 2017; Lesley, 2008; Moje et al., 2008) become significant when thinking about ways to nurture student willingness, particularly those who struggle, to persist with learning. The results of this study contribute to this body of work and offer new ways to consider how to foster adolescent willingness towards enhancing their literacy skills.

\section{Immediate and Long-Term Impacts of the Classroom Circle}

While this study reaffirms some of what is known about how to provoke adolescent interest in terms of topic and perceptions of task authenticity, it also highlights the pedagogy underlying the facilitation of the classroom circle as restorative practices intersected with the kinds of academic dialogue that are associated with literature and Socratic circles. Viewing participants' responses to the classroom circle revealed positive academic and social gains, particularly their increased engagement with texts, enhanced understanding of how to use their experiences as a filter through which to analyze and make meaning of texts and issues, and increased awareness of the benefits of working and learning from unfamiliar others. Overwhelmingly, by the end of the semester, participants identified the classroom circle as having a positive effect upon their communication skills and saw it as an authentic task (Behizadeh, 2014a, 2014b) in that they were able to interact with others they saw as different from themselves. We also found that the classroom circle fostered student stamina for learning, as they regularly persisted with the topic under discussion during, and following, the circle. In knowing that their personal examples were a relevant frame through which to examine texts, and that they were in a supportive space to do so, participants took risks with their thinking and created connections that revealed insights about themselves, others, texts under discussion, and contemporary issues. Restorative practices complement the kinds of literacy activities and events that regularly happen in ELA classrooms, particularly as learners are often encouraged to draw upon their personal experiences to navigate academic texts. Making personal connections, hearing how others made such connections, and seeing links between multiple interpretations and society, have been found to have a positive impact on adolescents' reading development (Francois, 2013; Langer, 2002;). Yet, to get to a place where learners, particularly late 
adolescents, are willing to share stories and insights about themselves, trust must be established. Learners who perceive a sense of belonging in classrooms are more likely to engage in cognitive effort to make learning possible (Walker \& Greene, 2009).

While the long-term effects of the classroom circle are currently unknown, based upon the evidence presented in our study, we suggest, participants are likely to experience better communication and interpersonal skills as well as enhanced critical engagement.

\section{Concluding Thoughts}

We acknowledge that there is no universal pedagogical solution and that there are many factors when understanding adolescents who encounter challenges with literacy (Bauer \& García, 2002; Dawson, 2009; Pitcher et al., 2010), while experiencing poverty (Ahmar \& Anwar, 2013; Reardon, 2011; Sirin, 2005). Considering, however, how restorative practices can be infused into the daily instructional practices (Gregory et al., 2016; Ortega et al., 2016) of ELA teachers is hopeful and warrants further inquiry. Daily routines such as a classroom circle, where trust is established, the personal is welcomed, and the aim is analytical thinking and dialogue, are reminiscent of what Buckelew and Ewing (2019) allude to as a "breathing space,"8 a space that allows for the fire of one's thinking to burn and strengthen.

The results of this study revealed how participants over the course of a high school semester came to see the classroom circle as relevant to their lives and learning. In response to this regular routine and its guidelines involving peaceful interactions, respect, relationship building, and trust, participants connected to each other, texts, and issues as they persisted with ideas. Taking risks with their thinking and making connections among texts became a regular occurrence, as they grew accustomed to the classroom circle, the support of this space, and the idea that personal experiences were a legitimate way to make meaning. Enabling adolescents who academically struggle to have more knowledge of themselves as thinkers with ideas to share (Vetter, 2010; Winn, 2013), and the kinds of approaches that allow them to do so, is an area in teacher education that holds promise for those engaged in supporting teachers and learners in high-poverty contexts.

\section{Endnotes}

${ }^{1}$ Lia was the teacher of this class and is the second author of this paper. All other names are pseudonyms.

${ }^{2}$ Night (Wiesel, 2006) is an autobiographical account of the author's survival as an adolescent in the Nazi death camps.

${ }^{3}$ Based on course enrolments in the Chignecto-Central Regional Centre of Education (CCRCE), the Regional Centre in which this study took place, there is a "disproportionately higher number of males and students of Indigenous ancestry enrolled in English Communications in comparison to other English courses at Grades 11 and 12" (CCRCE, 2019, p. 4).

${ }^{4}$ Campbell (2019) defined pedagogical bricolage as "a way of considering teaching not merely as a set of behaviours that determine certain outcomes, but as a concatenation of possibilities, realized in an infinite number of permutations by those who operate successfully within the teaching profession" (p. 38).

${ }^{5}$ The term late adolescents is used to define the age range $(17-21)$ of the participants in this study. 
${ }^{6}$ The term Regional Centre for Education is used to reflect what other school systems may refer to as school boards or districts.

${ }^{7}$ The Chignecto-Central Regional Centre of Education (CCRCE) created guidelines for relational principles for practice based upon a restorative approach (Llewellyn et al., 2013); these practices are identified as relationship focused, comprehensive/holistic, inclusive \& participatory, forward-focused, and culturally aware (CCRCE, n.d.).

${ }^{8}$ Buckelew and Ewing (2019) include Judy Brown's poem Fire as a poetry connection at the end of a Chapter in which data collection that is well suited for action research in ELA classrooms is discussed. 


\section{References}

Ahmar, F., \& Anwar, E. (2013). Socioeconomic status and its relation to academic achievement of higher secondary school students. IOSR Journal of Humanities and Social Science, 13(16), 13-20.

https://pdfs.semanticscholar.org/8e22/38e725ebb14b9a94f2ec7f72acdf1d98bd78.pdf

Allen, J., Möller, K. J., \& Stroup, D. (2003). "Is this some kind of soap opera?": A tale of two readers across literature discussion contexts. Reading \& Writing Quarterly, 19(3), 225251. doi: $10.1080 / 10573560308215$

Almasi, J. F., O'Flahavan, J. F., \& Arya, P. (2001). A comparative analysis of student and teacher development in more and less proficient discussions of literature. Reading Research Quarterly, 36(2), 96-120. doi: 10.1598/RRQ.36.2.1

Alvermann, D.E. (1995). Peer-led discussions: Whose interests are served? Journal of Adolescent \& Adult Literacy, 39(4), 282-289. https://www.jstor.org/stable/40013414

American Psychological Association Zero Tolerance Force. (2006). Are zero tolerance policies effective in the schools? An evidentiary review and recommendations. https://www.apa.org/pubs/info/reports/zero-tolerance-report.pdf

Aoki, T. (1993/2004). Chapter 9: Legitimating lived curriculum: Toward a curricular landscape of multiplicity. In W. P. Pinar and R. L. Irwin's (Eds.), Curriculum in a new Key: The collected works of Ted. T. Aoki. New York, NY: Routledge.

Balbay, S. (2019). Enhancing critical awareness through Socratic pedagogy. Eurasian Journal of Applied Linguistics, 5(3), 515-536. http://dx.doi.org/10.32601/ejal.651348

Batchelor, K. (2012). The "us" in discuss: Grouping in literature circles. Voices from the Middle, 20(2), 27-34. http://www.ncte.org/journals

Bauer, E. B., \& García, G. E. (2002). Lessons from a classroom teacher's use of alternative literacy assessment. Research in the Teaching of English, 36(4), 462-494. https://www.jstor.org/stable/40171586

Beach, R., Appleman, D., Fecho, B., \& Simon, R. (2016). Teaching literature to adolescents (3rd ed.). Oxfordshire, UK: Routledge.

Behizadeh, N. (2014a). Adolescent perspectives on authentic writing instruction. Journal of Language \& Literacy Education, 10(1), 27-44. https://files.eric.ed.gov/fulltext/EJ1030675.pdf

Behizadeh, N. (2014b). Xavier's take on authentic writing: Structuring choices for expression and impact. Journal of Adolescent and Adult Literacy, 58(4), 289-298. https://doi.org/10.1002/jaal.357

Benko, S. L. (2016). Instruction matters: Secondary English preservice teachers' implementation of cognitively demanding writing tasks. English Education, 48(3), 201-236.

Blum, H. T., Lipsett, L. R., \& Yocom, D. J. (2002). Literature circles: A tool for selfdetermination in one middle school inclusive classroom. Remedial and Special Education, 23(2), 99-108. doi:10.1177/074193250202300206 
Bond, T. F. (2001). Giving them free rein: Connections in student-led book groups. Reading Teacher, 54(6), 574-584. https://www.jstor.org/stable/20204957

Breslau, J., Miller, E., Breslau, N., Bohnert, K., Lucia, V., \& Schweitzer, J. (2009). The impact of early behavior disturbances on academic achievement in high school. Pediatrics, 123(6), 1472-1476. doi: 10.1542/peds.2008-1406

Brown, A.C. (2016). Classroom community and discourse: How argumentation emerges during a Socratic circle. Dialogic Pedagogy: An International Online Journal, 4, A81-A97. doi: 10.5195/dpj.2016.160

Brownell, M., Roos, N., Fransoo, R., Roos, L., Guevremont, A., MacWilliam, L., Yallop, L., \& Levin B. (2006). Is the class half empty? A population-based perspective on socioeconomic status and educational outcomes. IRPP Choices, 12(5) 1-30. https://irpp.org/research-studies/is-the-class-half-empty/

Brownell, M., Roos, Noralou P., MacWilliam, Leonard, Leclair, Leanne, Ekuma, Okechukwu, \& Fransoo, Randy. (2010). Academic and social outcomes for high-risk youths in Manitoba. Canadian Journal of Education, 33(4), 804-836. file://Users/jmitton/Downloads/2188Article\%20Text-8125-1-10-20160104.pdf

Butler-Kisber, L. (2010). Qualitative inquiry: Thematic, narrative and arts-informed perspectives. Thousand Oaks, CA: Sage.

Buckelew, M., \& Ewing, J. (2019). Action research for English language arts teachers: Invitation to inquiry. Oxfordshire, UK: Routledge.

Campbell, L. (2019). Pedagogical bricolage and teacher agency: Towards a culture of creative professionalism, Educational Philosophy and Theory, 51(1), 31-40. doi:

10.1080/00131857.2018.1425992

Carver-Thomas \& Darling-Hammond, (2019). The trouble with teacher turnover: How teacher attrition affects students and schools. Education Policy Analysis Archives, 27(36). http://dx.doi.org/10.14507/epaa.27.369

Casey, H. K. (2008). Engaging the disengaged: Using learning clubs to motivate struggling adolescent readers and writers. Journal of Adolescent \& Adult Literacy, 52(4), 284-294. https://www.jstor.org/stable/40058130

Chignecto-Central Regional Centre for Education (CCRCE). (2019, August). Thrive \& achieve: System improvement plan. https://ccrce.ca/sites/default/files/Documents\%20and\%20Forms/System-ImprovementPlan-LowRes.pdf

Chignecto-Central Regional Centre for Education (CCRCE). (n.d.). Relational principles for practice.

https://staff.ccrsb.ca/sites/default/files/Documents\%20and\%20Forms/Relational\%20Princ iples $\% 20$ for $\% 20$ Practice-Restorative $\% 20$ Approaches.pdf

Connelly, F. M., \& Clandinin, D. J. (1988). Teachers as curriculum planners: Narratives of experience. New York, NY: Teachers College Press. 
Clark, K. F. (2009). The nature and influence of comprehension strategy use during peer-led literature discussions: An analysis of intermediate grade students' practice. Literacy Research and Instruction, 48(2), 95-119. https://doi.org/10.1080/19388070802226295

Copeland, M. (2005). Socratic circles: Fostering critical and creative thinking in middle and high school. Portsmouth, NH: Stenhouse.

Corbett, M. (2005). Rural education and out-migration: The case of a coastal community. Canadian Journal of Education/Revue canadienne de l'éducation, 52-72. doi: $10.2307 / 1602153$

Costello, B., Wachtel, J., \& Wachtel, T. (2010). Restorative circles in schools: Building community and enhancing learning. Bethlehem, PA: International Institute for Restorative Practices.

Daniels, H. (2002). Literature circles: Voice and choice in book clubs and reading groups (2nd ed.). Portland, ME: Stenhouse.

Daniels, H. (2006). What's the next big thing with literature circles? Voices from the Middle, 13(4), 10-15. http://secondaryenglish.pbworks.com/f/smokey_whatsnext.pdf

Daniels, H., \& Steineke, N. (2003). Minilessons for literature circles. Portsmouth, NH: Heinemann.

Darragh, J. J., \& Boyd, A. S. (2019). Text selection: Perceptions of novice vs. veteran teachers, Action in Teacher Education, 41(1), 61-78. doi: 10.1080/01626620.2018.1533903

Dawson, C. M. (2009). Beyond checklists and rubrics: Engaging students in authentic conversations about their writing. English Journal, 98(5), 66-71. http://www.ncte.org/journals

Day, D., \& Kroon, S. (2010) “Online literature circles rock!”: Organizing online literature circles in a middle school classroom. Middle School Journal, November, 18-28. www.nmsa.org

Dean, J. S., Goering, C.Z., \& Nutt, T. (2016). Motivating dialogue: When seventh graders own their learning through discourse analysis. Voices from the Middle, 23(4), 19-24. http://www.ncte.org/journals

Dressman, M., Wilder, P., \& Connor, J. J. (2005). Theories of failure and the failure of theories: A cognitive/sociocultural/macrostructural study of eight struggling students. Research in the Teaching of English, 8-61. https://www.jstor.org/stable/40171672

Drewery, W., \& Kecskemeti, M. (2010). Restorative practice and behaviour management in schools: Discipline meets care. Waikato Journal of Education, 15(3), 101-113.

Downer, J., Sabol, T. J., \& Hamre, B. (2010). Teacher-child interactions in the classroom: Toward a theory of within- and cross-domain links to children's developmental outcomes. Early Education \& Development, 21, 699-723. doi:10.1080/10409289.2010.497453

Dunne, M. (2014). Addressing the Cinderella area: Using masters level study to support secondary English trainee teachers in developing effective teaching and assessment of speaking and listening. English in Education, 48(1), 93-107. doi:10.1111/eie.12033 
Eeds, M., \& Wells, D. (1989). Grand conversations: An exploration of meaning construction in literature study groups. Research in the Teaching of English, 23(1), 4-29. https://www.jstor.org/stable/40171286

Flowerday, T., Schraw, G., \& Stevens, J. (2004). The role of choice and interest in reader engagement. Journal of Experimental Education, 72(2), 93-114. https://www.jstor.org/stable/20157361

Fogarty, M. S., Davis, J. L., Anderson, L. L., \& Myint, A. (2017). Using relevance prompts: An exploratory study to promote eighth graders' comprehension and retelling of narrative text. Literacy Research and Instruction, 56(1), 54-67. doi: 10.1080/19388071.2016.1219927

Forzani, E., \& Leu, D. J. (2017). Multiple perspectives on literacy as it continuously changes: Reflections on opportunities and challenges when literacy is deictic. Journal of Education, 197(2), 19-24. https://doi.org/10.1177/002205741719700203

Francois, C. (2013). Reading is about relating: Urban youths give voice to the possibilities for school literacy. Journal of Adult \& Adolescent Literacy, 57(2), 141-149. doi: 10.1002/JAAL. 218

Frank, L., \& Fisher, L. (2019). 2019 report card on child and family poverty in Nova Scotia: Three decades lost. Canadian Centre for Policy Alternatives (CCPA). https://www.policyalternatives.ca/publications/reports/2019-report-card-child-andfamily-poverty-nova-scotia

Frank, L., \& Saulnier, C. (2017). 2017 report card on child and family poverty in Nova Scotia. Canadian Centre for Policy Alternatives (CCPA). https://www.policyalternatives.ca/publications/reports/2017-report-card-child-andfamily-poverty-nova-scotia

Franzak, J. K. (2006). Zoom: A review of the literature on marginalized adolescent readers, literacy theory, and policy implications. Review of Educational Research, 76(2), 209248. https://doi.org/10.3102/00346543076002209

Friesen, K. L., \& Stephens, C. M. (2016). Circles of learning: Applying Socratic pedagogy to learn modern leadership. Journal of Leadership Education, 15(1), 76-85. doi: $10.12806 / \mathrm{V} 15 / \mathrm{I} 1 / \mathrm{T} 1$

Ganske, K., Monroe, J. K., \& Strickland, D. S. (2003). Questions teachers ask about struggling readers and writers. The Reading Teacher, 57(2), 118-128. https:/www.learner.org/wpcontent/uploads/2019/02/Questions-Teachers-Ask-About-Struggling-Readers-andWriters-Qs_struggling_readers-Teaching-Diverse-Learners-Teaching-Reading-3-5Workshop.pdf

Gee, J. (2001). Reading as situated language: A sociocognitive perspective. Journal of Adolescent \& Adult Literacy, 44(8), 714-725. doi:10.1598/JAAL.44.8.3

Gee, J. P. (2007). Social linguistics and literacies: Ideology in discourses (3rd ed.). Oxfordshire, UK: Routledge.

Graveline, F. (1998). Circle works: Transforming Eurocentric consciousness. Halifax, Canada: Fernwood. 
Gregory, A., Clawson, K., Davis, A., \& Gerewitz, J. (2016). The promise of restorative practices to transform teacher-student relationships and achieve equity in school discipline. Journal of Educational and Psychological Consultation, 26(4), 325-353, doi: 10.1080/10474412.2014.929950

Higham, R. J. E., Brindley, S., \& Van de Pol, J. (2014). Shifting the primary focus: Assessing the case for dialogic education in secondary classrooms. Language and Education, 28(1), 86 99. doi:10.1080/09500782.2013.771655

International Institute of Restorative Practices (IIRP). (2009). Improving school climate: Findings from schools implementing restorative practices. http://www.iirp.edu/pdf/IIRPImproving-School-Climate.pdf

Ivey, G., \& Johnston, P. H. (2015). Engaged reading as a collaborative transformative practice. Journal of Literacy Research, 47(3), 297-327. https://doi.org/10.1177/1086296X15619731

Joffe, V. L., \& Black, E. (2012). Social, emotional, and behavioral functioning of secondary school students with low academic and language performance: Perspectives from students, teachers, and parents. Language, Speech, and Hearing Services in Schools, 43(4), 461-473. doi: 10.1044/0161-1461(2012/11-0088)

Josephs, N. L., \& Jolivette, K. (2016). Effects of peer mediated instruction on the oral reading fluency skills of high school aged struggling readers. Insights into Learning Disabilities, 13(1), 39-59. doi: 10.1177/00222194050380050501

Kalantzis, M., \& Cope, B. (2011). Literacies. New York, NY: Cambridge University Press.

Kane, S. (2011). Literacy \& learning in the content areas (3rd ed.). Scottsdale, AZ: Holcomb Hathaway.

Kim, J. S., Hemphill, L., Troyer, M., Thomson, J. M., Jones, S. M., LaRusso, M. D., \& Donovan, S. (2017). Engaging struggling adolescent readers to improve reading skills. Reading Research Quarterly, 52(3), 357-382. https://doi.org/10.1002/rrq.171

Langer, J. A. (2002). Effective literacy instruction: Building successful reading and writing programs. Urbana, IL: National Council on Teachers of English.

Lesley, M. (2008). Access and resistance to dominant forms of discourse: Critical literacy and "at risk" high school students. Literacy Research and Instruction, 47(3), 174-194. https://doi.org/10.1080/19388070802062716

Leu, D. J. (2000). Literacy and technology: Deictic consequences for literacy education in an information age. In M. L. Kamil, P. B. Mosenthal, P. D. Pearson, \& R. Barr (Eds.), Handbook of reading research (vol. 3, pp. 743-70). Mahwah, NJ: Erlbaum.

Leu, D. J., Kinzer, C. K., Coiro, J., Castek, J., \& Henry, L. A. (2013). New literacies: A dual level theory of the changing nature of literacy, instruction, and assessment. In D. E. Alvermann, N. J. Unrau, \& R. B. Ruddell (Eds.), Theoretical models and processes of reading (6th ed., pp. 1150-1181). Washington, DC: International Reading Association. http://www.literacyworldwide.org/docs/default-source/bonus-materials/710-chapter42.pdf 
Lind, A. (2008). Literacy for all: Making a difference. Paris: UNESCO International Institute for Educational Planning. http://www.unesco.org/new/en/education/themes/educationbuilding-blocks/literacy/resources/key-publications/

Llewellyn, J. J., Archibald, B., Clairmont, D., \& Crocker, D. (2013). Imagining success for a restorative approach to justice: Implications for measurement and evaluation. Dalhousie Law Journal, 36(2), 281-316.

https://poseidon01.ssrn.com/delivery.php?ID=4350990020921250951220820970721171

071050860540360360180760050010251220240061091250231191261221000230560200 890971231030180990080060740490050290990750821070740171060730020481220920 85000126111006016068118065080080068126027120098108113123022094013095068 $\& \mathrm{EXT}=\mathrm{pdf}$

Lovett, M. W., Lacerenza, L., De Palma, M., \& Frijters, J. C. (2012). Evaluating the efficacy of remediation for struggling readers in high school. Journal of Learning Disabilities, 45(2), 151-169. doi: 10.1177/0022219410371678

McCarthey, S. J., \& Moje, E.B. (2002). Conversations: Identity matters. Reading Research Quarterly, 37(2), 228. https://www.jstor.org/stable/748158

McElvain, C. M. (2010). Transactional literature circles and the reading comprehension of English learners in the mainstream classroom. Journal of Research in Reading, 33(2), 178-205. doi: 10.1111/j.1467-9817.2009.01403.x

Merriam, S. B., \& Tisdell, E. J. (2016). Qualitative research: A guide to design and implementation $\left(4^{\text {th }}\right.$ ed.). San Francisco, CA: Jossey-Bass.

Minguela, M., Solé, I., \& Pieschl, S. (2015). Flexible self-regulated reading as a cue for deep comprehension: Evidence from online and offline measures. Reading and Writing, 28(5), 721-744. doi: 10.1007/s11145-015-9547-2

Mitton, J., \& Murray-Orr, A. (in review). Identifying the impact of culturally relevant pedagogy: Evidence of academic risk taking in culturally and economically diverse Nova Scotia classrooms.

Moeller, M., \& Moeller, V. (2013). Socratic circles and literature circles. Oxfordshire, UK: Routledge.

Moje, E. B., Overby, M., Tysvaer, N., \& Morris, K. (2008). The complex world of adolescent literacy: Myths, motivations, and mysteries. Harvard Educational Review, 78(1), 107154. http://wwwpersonal.umich.edu/ moje/pdf/Journal/TheComplexWorldOfAdolescentLiteracy.pdf

Moskal, N.A. (2019). "I'm gonna buy all those books!": Reality pedagogy and literature circles. English Journal, 109(2), 54-60.

https://secure.ncte.org/library/NCTEFiles/Resources/Journals/EJ/1092nov2019/EJ1092Nov19Gonna.pdf

Murphy, A., Franklin, S., Breen, A., Hanlon, M., McNamara, A., Bogue, A., \& James, E. (2017). A whole class teaching approach to improve the vocabulary skills of adolescents attending mainstream secondary school, in areas of socioeconomic disadvantage. Child Language Teaching and Therapy, 33(2), 129-144. https://doi.org/10.1177/0265659016656906 
Noddings, N. (2013). The challenge to care in schools ( $2^{\text {nd }}$ ed.). Oakland, CA: University of California Press.

NS Government. (n.d.). Restorative approaches in schools.

https://novascotia.ca/just/prevention/restorative_approaches_in_schools.asp

Nystrand, M. (2006). Research on the role of classroom discourse as it affects reading comprehension. Research in the Teaching of English, 40(4), 392-412. https://www.jstor.org/stable/40171709

OECD. (2018). A broken social elevator? How to promote social mobility. Paris, France: OECD Publishing. https://doi.org/10.1787/9789264301085-en

Ortega, L., Lyubansky, M., Nettles, S., \& Espelage, D. L. (2016). Outcomes of a restorative circles program in a high school setting. Psychology of Violence, 6(3), 459-468. http://dx.doi.org/10.1037/vio0000048

Pahl, K., \& Rowsell, J. (2012). Literacy and education: The new literacy studies in the classroom (2nd ed.). Thousand Oaks, CA: Sage.

Peralta-Nash, C., \& Dutch, J. A. (2000). Literature circles: Creating an environment for choice. Primary Voices K-6, 8(4), 29-37. https://library.ncte.org/journals/pv/issues/v8-4

Peltier, S. (2017). An Anishinaabe perspective on children's language learning to inform "seeing the Aboriginal child." Language and Literacy, 19(2), 4-19. https://doi.org/10.20360/G2N95C

Peskin, J., Allen, G., \& Wells-Jopling, R. (2010). “The educated imagination”: Applying instructional research to the teaching of symbolic interpretation of poetry. Journal of Adolescent \& Adult Literacy, 53(6), 498-507. doi: 10.1598/JAAL.53.6.6

Pete, S. (2004). The circle as pedagogy: Creating authentic elder/youth engagement. Centre of excellence for children's well-being: Youth engagement. https://archives.studentscommission.ca/pdf/CircleAP_FINAL.pdf

Phegley, M. N., \& Oxford, J. (2010). Cross-level collaboration: Students and teachers learning from each other. English Journal, 99(5), 27-34. https://www.jstor.org/stable/27807188

Piazza, S. V., \& Duncan, L. E. (2012). After-school literacy engagements with struggling readers. Reading \& Writing Quarterly, 28(3), 229-254. http://www.tandf.co.uk/journals

Pitcher, S. M., Martinez, G., Dicembre, E. A., Fewster, D., \& McCormick, M. K. (2010). The literacy needs of adolescents in their own words. Journal of Adolescent \& Adult Literacy, 53(8), 636-645. https://doi.org/10.1598/JAAL.53.8.2

Pittman, P., \& Honchell, B. (2014). Literature discussion: Encouraging reading interest and comprehension in struggling middle school readers. Journal of Language and Literacy Education, 10(2), 118-133. https://pdfs.semanticscholar.org/5bfe/dcac0c5cd3fcb4c3639022645b1f69162e09.pdf?_ga $=2.267233166 .1026607012 .1590516076-453846732.1590516076$

Reardon, S. F. (2011). Chapter 5: The widening academic achievement gap between the rich and the poor: New evidence and possible explanations. In G. J. Duncan \& R. J. Murnane (Eds.), Whither opportunity: Rising inequality, schools, and children's life chances (pp. 
91-116). New, NY: Russell Sage Foundation/Spencer Foundation.

https://www.jstor.org/stable/10.7758/9781610447515

Roos, N. P., Brownell, M., Guevremont, A., Fransoo, R., Levin, B., MacWilliam, L., \& Roos, L. L. (2006). The complete story: A population-based perspective on school performance and educational testing. Canadian Journal of Education/Revue canadienne de l'éducation, 684-705. https://www.jstor.org/stable/20054191?seq=1\#metadata_info_tab_contents

Rosenblatt, L.M. (1995). Literature as exploration (5th ed.). New York, NY: Modern Language Association of America.

Sanacore, J. (2013). "Slow down, you move too fast": Literature circles as reflective practice. The Clearing House: A Journal of Educational Strategies, 86(3), 116-120. doi: 10.1080/00098655.2013.773270

Scheffel, T. (2012). Individual pathways to literacy engagement: Three portraits. Brock Education, 21(2), 1. https://www.oalib.com/journal/4985/1\#.Xs 1ZqC-z2S4

Scheffel, T. (2016). Individual paths to literacy engagement: Three narratives revisited. Brock Education: A Journal of Educational Research and Practice, 25(2), 53-70. doi: 10.26522/brocked.v25i2.500

Scheffel, T. (2017). Tell me with pictures! Grade 8 students' digital representations of engagement in learning. McGill Journal of Education/Revue des sciences de l'éducation de McGill, 52(3), 719-746. https://mje.mcgill.ca/article/view/9357/7307

Schumacher, A. (2014). Talking circles for adolescent girls in an urban high school: A restorative practices program for building friendships and developing emotional literacy skills. Sage Open, October-December, 1-13. doi: 10.1177/2158244014554204

Schoffner, M., De Olivera, L.C., \& Angus, R. (2010). Multiliteracies in the secondary English classroom: Becoming literate in the $21^{\text {st }}$ century. English Teaching: Practice and Critique, 9(3), 75-89. http://education.waikato.ac.nz/research/files/etpc/files/2010v9n3art5.pdf

Schwab, J.J. (1983). The practical 4: Something for curriculum professors to do. Curriculum Inquiry, 13(3), 239-265. https://www.jstor.org/stable/1179606

Scribner, S., \& Cole, M. (1981). The psychology of literacy. Boston, MA: Harvard University Press.

Singer, J. Y., \& Smith, S. A. (2003). The potential of multicultural literature: Changing understanding of self and others. Multicultural Perspectives, 5(2), 17-23. doi: 10.1207/S15327892MCP0502_4

Sirin, S. R. (2005). Socio-economic status and academic achievement: A meta-analytical review of educational research. Review of Educational Research, 75(3), 417-453. https://research.steinhardt.nyu.edu/scmsAdmin/media/users/lec321/Sirin_Articles/Sirin_2 005.pdf

Skerrett, A., \& Bomer, R. (2011). Borderzones in adolescents' literacy practices: Connecting out-of-school literacies to the reading curriculum. Urban Education, 46(6), 1256-1279. https://doi.org/10.1177/0042085911398920 
Street, B.V. (1995). Social literacies: Critical approaches to literacy in development, ethnography and education. London, UK: Longman.

Statistics Canada. (2019). Canadian income survey, 2019. The Daily. https://www150.statcan.gc.ca/n1/daily-quotidien/190226/dq190226b-eng.htm

Statistics Canada. (2020). Canada's official poverty dashboard indicators: Snapshot, September 2020. https://www150.statcan.gc.ca/n1/en/pub/11-627-m/11-627-m2020065eng.pdf?st=MpdEMmCt

Styslinger, M. E., \& Overstreet, J. F. (2014). Strengthening argumentative writing with speaking and listening (Socratic) circles. Voices from the Middle, 22(1), 58-62. https://secure.ncte.org/library/NCTEFiles/Resources/Journals/VM/0221sep2014/VM0221Strength.pdf

Styslinger, M. E., \& Pollock, T. (2010). The chicken and the egg: Inviting response and talk through Socratic circles. Voices from the Middle, 18(2), 36-45. https://library.ncte.org/journals/vm/issues/v18-2

Su, Y., \& Wu, K.H. (2016). How literature circles support EFL college students' literacy and literacy learning in a children's and adolescent literature course. International Journal for Cross-Disciplinary Subjects in Education (IJCDSE), 7(3), 2874-2879. https://infonomics-society.org/wp-content/uploads/ijcdse/published-papers/volume-72016/How-Literature-Circles-Support-EFL-College-Students-Literary-and-LiteracyLearning.pdf

Thein, A. H., Guise, M., \& Sloan, D. L. (2011). Problematizing literature circles as forums for discussion of multicultural and political texts. Journal of Adolescent \& Adult Literacy, 55(1), 15-24. doi: 10.1598/JAAL.55.1.2

Thomas, C., \& Goering, C.Z. (2018). Socratic circles in world history: Reflections on a year in dialogue. The Clearing House: A Journal of Educational Strategies, Issues and Ideas, 91(3), 103-110. doi: 10.1080/00098655.2017.1411132

Thompson, G., Madhuri, M., \& Taylor, D. (2008). How the Accelerated Reader program can become counterproductive for high school students. Journal of Adolescent \& Adult Literacy, 51(7), 550-560. doi: 10.1598/JAAL.51.7.3

Troyer, M. (2017). A mixed-methods study of adolescents' motivation to read. Teachers College Record, 119(5). https://www.tcrecord.org/Issue.asp?volume=119\&number $=5 \&$ volyear=2017

United Nations Educational, Scientific and Cultural Organization (UNESCO). (2008). A review of concepts, methodology and current data. Montreal: UNESCO Institute for Statistics. Retrieved from http://unesdoc.unesco.org/images/0016/001628/162808e.pdf

Van Zoost, S. (2011). Changes and possibilities: A case study of Nova Scotia classroom assessment policies. Journal of Education Policy, 26(1), 83-94. https://doi.org/10.1080/02680939.2010.498899

Vetter, A. (2010). Positioning students as readers and writers through talk in a high school English classroom. English Education, 43(1), 33-65. https://www.jstor.org/stable/23017083 
Walker, C. O. \& Greene, B. A. (2009). The relations between student motivational beliefs and cognitive engagement in high school. The Journal of Educational Research, 102(6), 463471. doi: 10.3200/JOER.102.6.463-472

Watchel, W. (2016). Defining restorative. International Institute for Restorative Practices. https://www.iirp.edu/images/pdf/Defining-Restorative_Nov-2016.pdf

Whittaker, C. (2012). Integrating literature circles into a cotaught inclusive classroom. Intervention in School and Clinic, 47(4), 214-223. doi: 10.1177/1053451211424601

Wiesel, E. (2006). Night ( $2^{\text {nd }}$ ed.). New York, NY: Hill and Wang.

Winn, M.T. (2013). Toward a restorative English education. Reading in the Teaching of English, 48(1), 126-136. https://education.ucdavis.edu/sites/main/files/fileattachments/winn rte13-1 toward restorative.pdf

Yin, R. K. (2018). Case study research and applications: Design and methods (6 ${ }^{\text {th }}$ ed.). Thousand Oaks, CA: Sage.

Yin, R. K., \& Davis, D. (2007). Adding new dimensions to case study evaluations: The case of evaluating comprehensive reforms. New Directions for Evaluation, 113, 75-93. doi: $10.1002 /$ ev. 216

Young, C., \& Mohr, K. A. J. (2018). Exploring factors that influence quality literature circles. Literacy Research and Instruction, 57(1), 44-58. doi: 10.1080/19388071.2017.1366606 